\section{Electrochemical characterization of micro- and nano-particles of ceftriaxone in human blood serum samples using cyclic voltammetry}

Muhammed Mizher RADHI - Radiological Techniques Department, Health and Medical Technology College-Baghdad, Iraq · mmradhi@yahoo.com

InTESAR NADHum KHELKAL - Biology Department, Science College, Mustansiriah University

Eman NATIQ NAJI - Biology Department, Science College, Mustansiriah University

ALAA LAEBI ABDULLAH - Biology Department, Science College, Mustansiriah University

Érkezett: 2019. 02. 02. - Received: 02. 02. 2019. " https://doi.org/10.14382/epitoanyag-jsbcm.2019.10

\section{Abstract}

The present study has selected one important antibiotic compound in a microcrystalline of ceftriaxone (CRX) and then it was converted into nano-particles (NPS) by lyophilization (freezedrying method). The CRX NPs was characterized by electrochemical analysis using cyclic voltammetric method by glassy carbon electrode (GCE) in human blood serum medium. It was found that CRX has oxidation-reduction current peaks at 0.9 and $-0.75 \mathrm{~V}$ respectively, while the cyclic voltammogram of CRX NPs was illustrated the reduction current peak at $-0.75 \mathrm{~V}$ and the oxidation peak cannot be seen, so this phenomena explains that CRX NPs act as antioxidant antibiotic in serum medium. Also, the study included the electrochemical behavior of nano antibiotic CRX NPs in different pH and concentration. Scanning electron microscopy (SEM) and atomic force microscopy (AFM) was applied.

Keywords: ceftriaxone, cyclic voltammetry, antibiotic nano-particles, serum medium Kulcsszavak: ceftriaxon, ciklikus voltammetria, antibiotikum nano-részecskék, vérsavó közeg
Muhammed Mizher RADHI

Professor, Department of Radiological Techniques, Health and Medical Technology College-Baghdad, Middle Technical University, Baghdad, Iraq. Received his PhD from University Putra of Malaysia (UPM) in 2010 in Electrochemistry, Nanotechnology. Research topics: conductivity of grafted polymer with nano-deposit and fabrication of sensors by nanomaterials to study drugs in blood medium by electrochemical analysis.

Intesar N. KHELKAL Professor in the Department of Biology and Microbiology, Mustansiriah University, College of Science. Received her Bachelor's degree in science at Baghdad University, College of Science, Department of Biology (1991). Received her MSc and PhD degrees in Microbiology at Mustansiriah University $(1998,2004)$. Her study focused on pathogenic bacteria, Physiology and taxonomy. Currently she is a lecturer in Biology department, College of Science, Mustansiriah University, Iraq, Baghdad.

Eman Natiq NAJI Professor in the Department of Biology and Microbiology, Mustansiriah University, College of Science. Received her Bachelor's degree in science at Baghdad University, College of Science, Department of Biology (1994). Received her MSc and PhD degrees in Microbiology at Mustansiriah University $(1998,2004)$. Her study focused on pathogenic bacteria and viruses, diagnostic microbiology and laboratory techniques. Currently she is a lecturer in Biology department, College of Science, Mustansiriah University, Iraq, Baghdad.

Alaa Laebi ABDULLAH Received her Bachelor's degree in science at Baghdad University, College of Science, Department of Biology (2009). Received his MSc degree in Microbiology at Mustansiriah University (2015). Currently he is PhD student in Mustansiriah University, College of Science, Department of Microbiology.

\section{Introduction}

Currently scientists have been studied the redox process of nano antibiotics to find the mechanism of oxidative effect in whole blood or serum media of in vitro study [1-6].

Ceftriaxone, sold under the trade name Rocephin, is an antibiotic useful for the treatment of a number of bacterial infections. Ceftriaxone is commercially available as a white to yellowish-orange crystalline powder for reconstitution, the structure of ceftriaxone is shown in Fig. 1 [7].

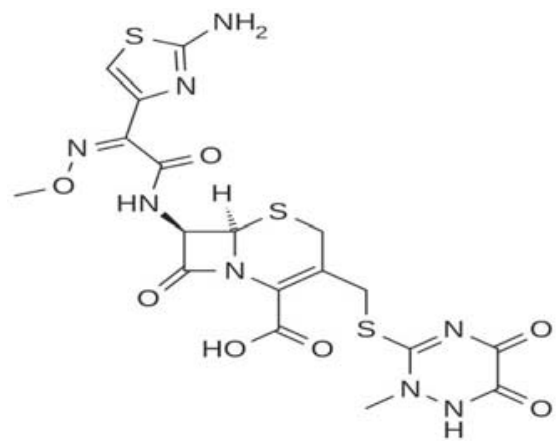

Fig. 1. Chemical structure of ceftriaxone micro-particles

1. ábra Ceftriaxone mikro-részecskék kémiai szerkezete
Electrochemical studies have been carried out on ceftriaxone by glassy carbon (GC-CNT) electrode modified with carbonnanotube in a phosphate buffer solution, $\mathrm{pH}=7.40$. Cyclic voltammetric technique was indicated that the oxidation process is irreversible and diffusion-controlled. The number of electrons exchanged in ceftriaxone is oxidized via a oneelectron step of oxidation process. Diffusion coefficient of ceftriaxone was found to be $2.74 \times 10^{-6} \mathrm{~cm}^{2} \mathrm{~s}^{-1}$. Ceftriaxone has a detection limit of $4.03 \times 10^{-6} \mathrm{M}$ in the study [8].

Electrochemical sensor based on the use of Nafion/MWCNT modified screen-printed carbon electrodes (SPCEs) was used to study this antimycobacterial drug in human urine and human blood serum samples. Nafion/MWCNT-SPCEs provided excellent biocompatibility, good electrical conductivity, low electrochemical interferences and a high signal-to-noise ratio, providing excellent performance towards ETB quantification in microvolumes of human urine and human blood serum samples [9].

Cyclic voltammetric technique was used to determine ceftizoxime by a modified glassy carbon electrode with a film of nano-diamond/graphite nano-mixture decorated with $\mathrm{Ag}$ nano-particles (AgNPs/NDG/GCE). The prepared modified 
electrode has good electrochemical properties such as simple preparation, high sensitivity, excellent repeatability and reproducibility and long-term stability [10].

Ceftizoxime (CFX) is used to reduce the infection caused by both gram-negative and gram-positive bacteria. The study included silver and gold nano-particles (Ag/AuNPs) on 5-(5-bromo-2-hydroxybenzylidenamino)-2 mercaptobenzimidazole and GCE was used to determine the electrochemical properties of CFX with good results of the detection limit which was calculated to be $2.0 \times 10-12 \mathrm{M}$. Also, the experimental variables such as deposited amount of the modifier suspension, $\mathrm{pH}$ of the supporting electrolyte and accumulation potential and time were optimized $[11,12]$.

In this study, the electrochemical analysis was included cyclic voltammetric technique to determine the chemical properties of ceftriaxone at micro- and nano-particles in blood serum medium.

\section{Experimental}

\subsection{Preparation of ceftriaxone nanoparticles}

Lyophilization (freezing method) was used to prepare ceftriaxone nano-particles by dissolving $0.75 \mathrm{~g}$ of ceftriaxone micro particles in $150 \mathrm{ml}$ of distilled water. The ceftriaxone suspension was cooled and the ice crystals of pure water formed at $-18{ }^{\circ} \mathrm{C}$. The second step involved blending the ice from the frozen product by passing thermal air from the lyophilization tool rack to the frozen solution in the flask, and leaking the flying ice and water vapor through the dried part of the product to the surface of the material. Water vapor is transported from the product surface through the chamber to the condenser, and the water vapor condenses on the condenser. At the end of the sublimation step a porous dam is formed. Its pores correspond to the areas occupied by ice crystals. The third step is drying that involves removing the absorbed water from the product. All steps must be continuous for about 48-72 hours [13].

\subsection{Materials}

Ceftriaxone compound in the form of yellowish powder was bought from HANGZHU Ruijiang Chemical (China) and blood samples were extracted from healthy humans which received from the center medicine of Baghdad City was used in the analysis after separation of the serum from the whole blood by electric centrifuge type $8-1$ (3000 cycles/min) . Deionized water was used for the preparation of aqueous solutions. All the serum of blood samples were diluted with deionized water by a ratio of 1:9 mL (serum: deionized water), $10 \mathrm{~mL}$ of diluted serum was replaced in the cyclic voltammetric cell.

\subsection{Apparatus}

\subsubsection{Cyclic voltammetric technique}

Instrument series EZstat (Potentiostat / Glvanostat) from NuVantSystems Company(USA) was used. The electrochemical analytical cell was connected with the potentio-stat device and monitored through a program that was installed on the PC to conduct periodic voltammetry (CV). Silver electrode contains silver/silver chloride $(\mathrm{Ag} / \mathrm{AgCl}$ in $3 \mathrm{M} \mathrm{KCl})$ and platinum wire (diameter $1 \mathrm{~mm}$ ) was used as reference and counter electrodes respectively. The glass working carbon electrode (GCE) was used in this study after cleaning by polishing with an alumina solution and treated with ultrasonic water path for ten minutes for measurement performance.

\subsubsection{Lyophilization instrument}

Lyophilization instrument from LABCONCO Company (USA) was used for the preparation of ceftriaxone nanoparticles from micro-particles by deep freezing technique as shown in Fig. 2.

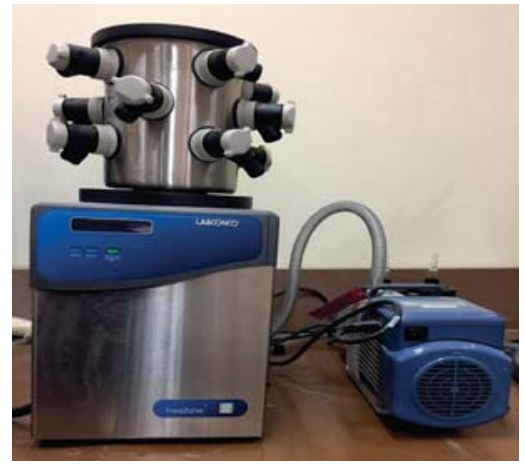

Fig. 2. Lyophilization instrument, LABCONCO Company (USA) 2. ábra Liofilizáló készülék LABCONCO Company (USA)

\subsection{Scanning Electron Microscopy (SEM)}

Fig. 3 shows the Scanning Electron Microscopy of the prepared ceftriaxone nano-particles which illustrates the morphology details of the nano-particles as spherical forms with diameter range of $20-38 \mathrm{~nm}$.

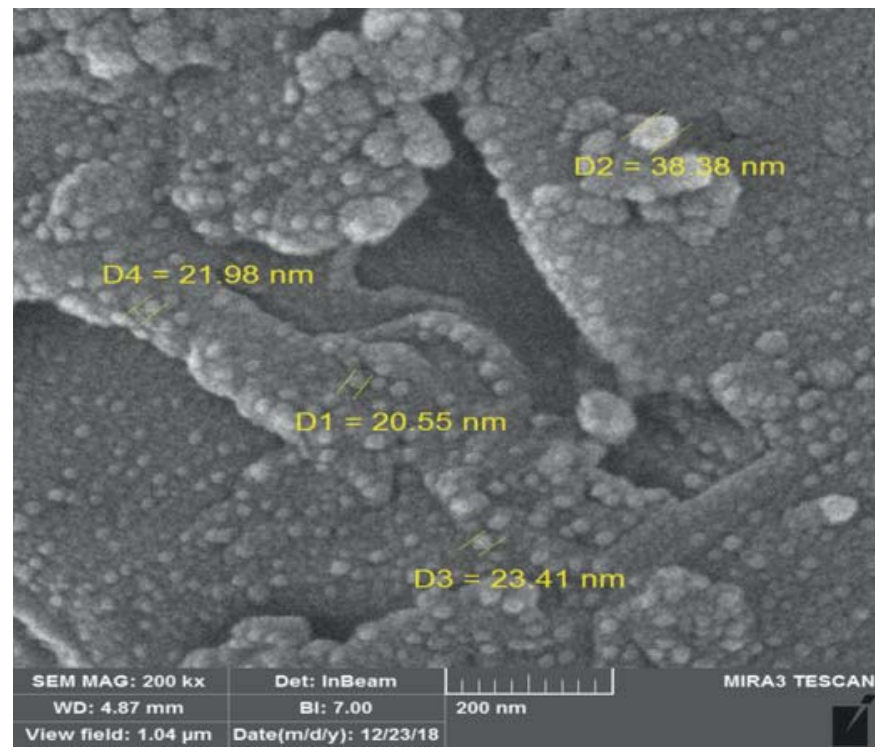

Fig. 3. SEM of the ceftriaxone nano-particles

3. ábra Ceftriaxon nano-részecskék pásztázó elektronmikroszkópos felvétele

\subsection{Atomic Force Microscopy (AFM)}

Atomic Force Microscopy technique was used to identify the diameter of the nano-particles. The diameter of the prepared ceftriaxone nano-particles was found as average diameter of 115 nm, shown in Figs. 4 and 5 together with Table 1. 


\begin{tabular}{ccccccccc}
$\begin{array}{c}\text { Diameter } \\
(\mathrm{nm})<\end{array}$ & Volume (\%) & $\begin{array}{c}\text { Cumulation } \\
(\%)\end{array}$ & $\begin{array}{c}\text { Diameter } \\
(\mathrm{nm})<\end{array}$ & Volume (\%) & $\begin{array}{c}\text { Cumulation } \\
(\%)\end{array}$ & $\begin{array}{c}\text { Diameter } \\
(\mathrm{nm})<\end{array}$ & $\begin{array}{c}\text { Volume (\%) } \\
(\%)\end{array}$ & $\begin{array}{c}\text { Cumulation } \\
(\%)\end{array}$ \\
\hline 60.00 & 0.32 & 0.32 & 100.00 & 9.39 & 23.30 & 140.00 & 17.80 & 87.38 \\
\hline 70.00 & 1.62 & 1.94 & 110.00 & 13.92 & 37.22 & 150.00 & 12.62 & 100.00 \\
\hline 80.00 & 5.50 & 7.44 & 120.00 & 15.86 & 53.07 & & & \\
\hline 90.00 & 6.47 & 13.92 & 130.00 & 16.50 & 69.58 & &
\end{tabular}

Table 1. Diameter $(\mathrm{nm})$ of the prepared ceftriaxone nano-particles 1. táblázat Ceftriaxon nano-részecskék átméröje $(\mathrm{nm})$

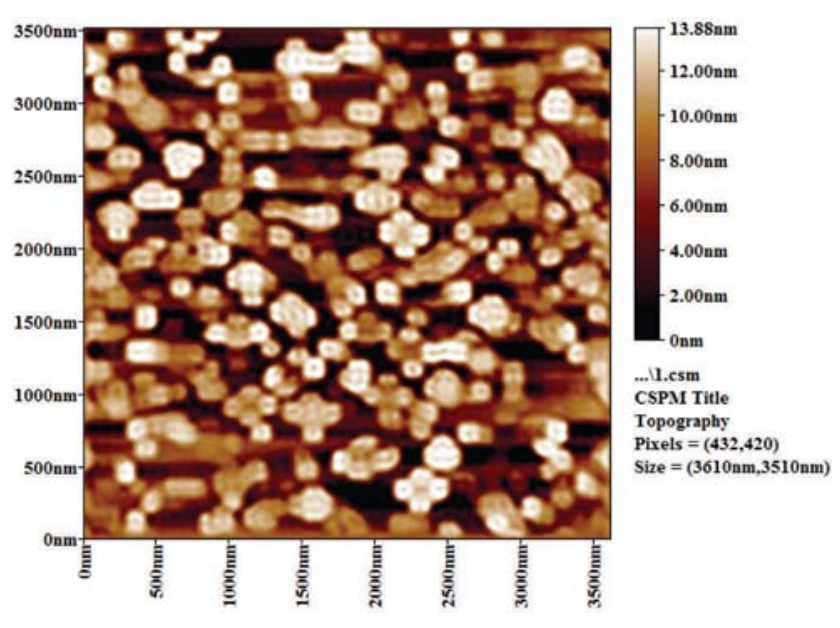

Fig. 4. AFM of the ceftriaxone nano-particles

4. ábra Ceftriaxon nano-részecskék AFM felvétele

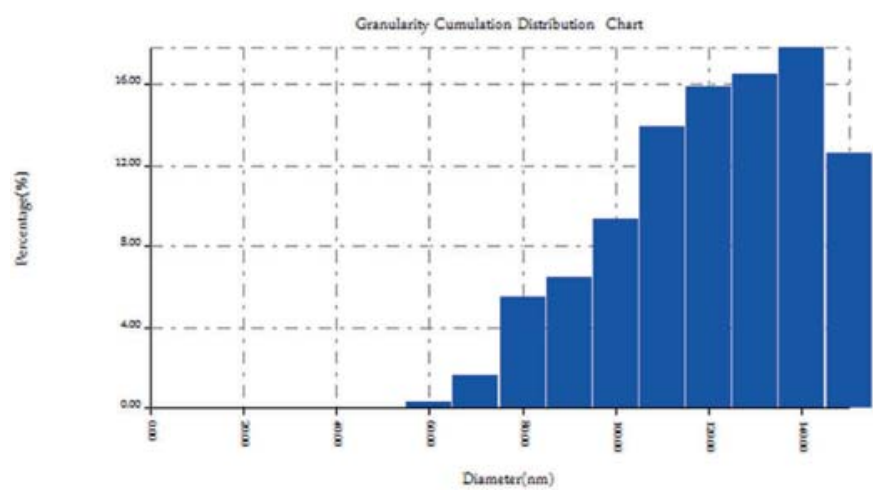

Fig. 5. Cumulative distribution diagram of ceftriaxone nano-particles diameter 5. ábra Ceftriaxon nano-részecskék átméröjének kumulatív eloszlása

\section{Results and discussion}

\subsection{Effect ceftriaxone micro- and nano-particles on blood} serum components

The comparison study between the micro- and nano-particles of ceftriaxone was characterized in blood serum medium by cyclic voltammetric technique at GCE as working electrode and $\mathrm{Ag} / \mathrm{AgCl}$ as reference electrode. Fig. 6 illustrates the oxidation current peak of ceftriaxone micro-particles at $1.0 \mathrm{~V}$ potential which disappeared in nano-particles form of the compound. But, the reduction current peak of ceftriaxone in both microand nano-particles was still present without any change in the blood serum medium. So, the ceftriaxone nanoparticles act as antioxidant reagent in blood serum medium. It can be used as antibiotic for different bacterial diseases without any side effects in the human body [14].

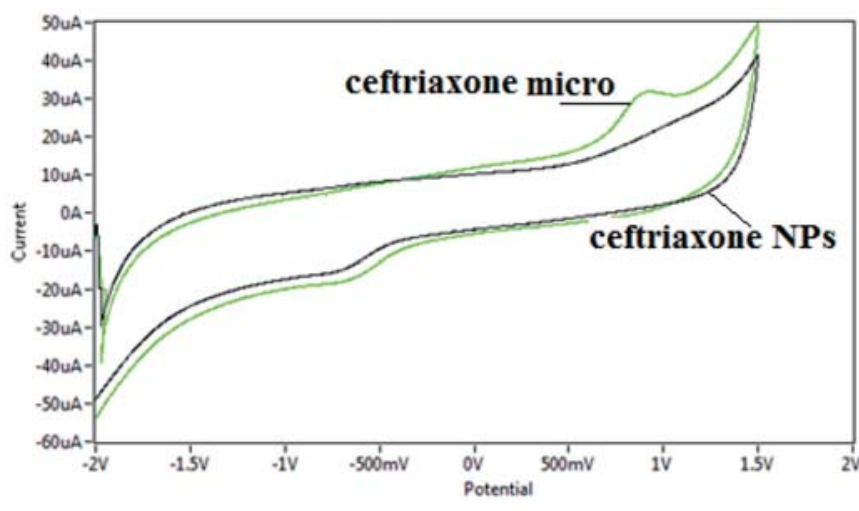

Fig. 6. Cyclic voltammogram of ceftriaxone micro- and nano-particles in blood serum medium at GCE as working electrode and $\mathrm{Ag} / \mathrm{AgCl}$ as reference electrode

6. ábra Ceftriaxon mikro- és nano-részecskék ciklikus voltammogramja vérsavó közegben; mérö elektróda: $\mathrm{GCE}$, referencia elektróda: $\mathrm{Ag} / \mathrm{AgCl}$

\subsection{Effect of different serum $\mathrm{pH}$ on ceftriaxone micro- and} nano-particles

The normal blood medium has a neutral $\mathrm{pH}=7$ especially with the ceftriaxone micro particles and oxidation-reduction current peaks were found at +0.9 and $-0.75 \mathrm{~V}$ respectively, but in the same $\mathrm{pH}$ (7) with ceftriaxone nano-particles reduction current peak was found at $-0.75 \mathrm{~V}$ and disappearing the oxidation peak as shown in Fig. 6. So the ceftriaxone nanoparticles act as anti-oxidative antibiotic reagent.

\subsubsection{Acidic medium}

It was found from the results that acidic $(\mathrm{pH}=3)$ serum blood medium affected the electrochemical properties of the oxidation-reduction current peaks of the ceftriaxone micro-particles which acted as oxidative antibiotic reagent as shown in Fig. 7. Also, the same phenomena was found in the ceftriaxone nano-particles in acidic $(\mathrm{pH}=3)$ blood serum medium as shown in Fig. 8.

\subsubsection{Alkaline medium}

It was found in the results with alkaline $(\mathrm{pH}=12)$ blood serum medium that for both the micro- and nano-particles of ceftriaxone the oxidation current peak disappeared and the reduction peak enhanced as shown in Figs. 7 and 8, so we can consider the alkaline medium of the blood serum as a good medium for anti-oxidative antibiotic reagent of ceftriaxone. 


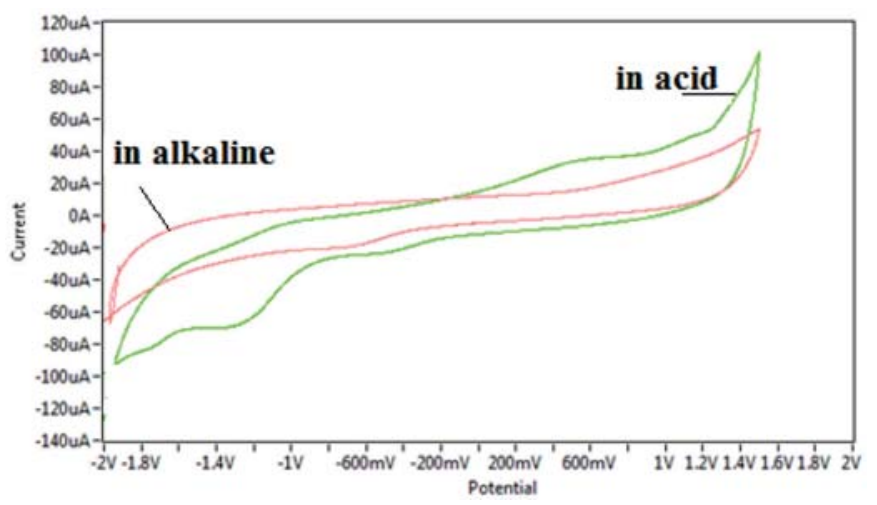

Fig. 7. Cyclic voltammograms for different $\mathrm{pH}$ (acidic and alkaline) blood serum medium with ceftriaxone micro-particles at GCE as working electrode and $\mathrm{Ag} / \mathrm{AgCl}$ as reference electrode

7. ábra Ceftriaxon mikro-részecskék ciklikus voltammogramja eltérő kémhatású (savas és lúgos) vérsavó közegben; méró elektróda: GCE, referencia elektróda: $\mathrm{Ag} / \mathrm{AgCl}$

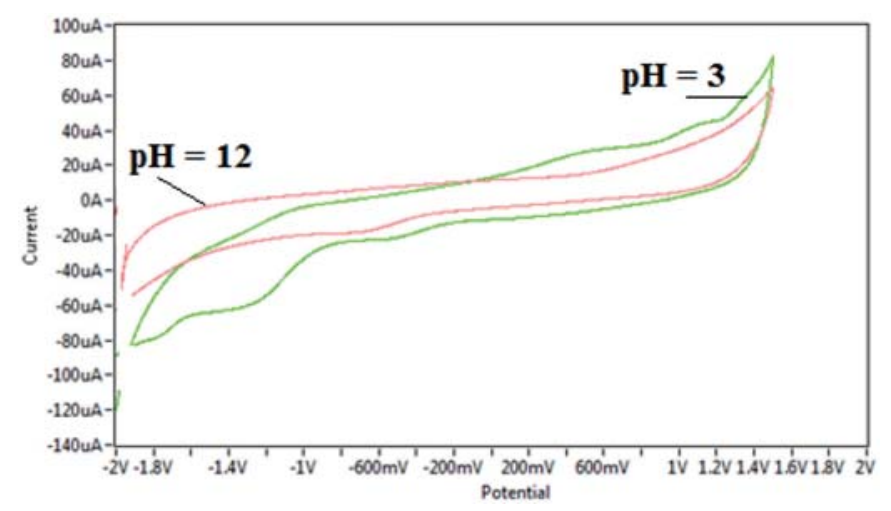

Fig. 8. Cyclic voltammograms for different $\mathrm{pH}$ (3 and 12) of blood serum medium with ceftriaxone nano-particles at GCE as working electrode and $\mathrm{Ag} / \mathrm{AgCl}$ as reference electrode

8. ábra Ceftriaxon nano-részecskék ciklikus voltammogramja eltérö kémhatású (spH 3 és 12) vérsavó közegben; mérö elektróda: GCE, referencia elektróda: $\mathrm{Ag}$ / $\mathrm{AgCl}$

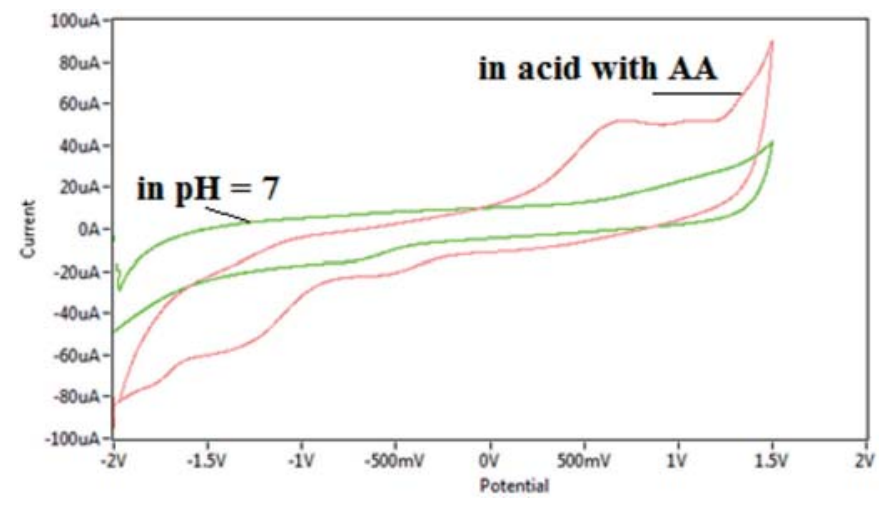

Fig. 9. Cyclic voltammogram of the ceftriaxone nano-particles in blood serum medium with and without $A A$ with GCE as working electrode and $\mathrm{Ag} / \mathrm{AgCl}$ as reference electrode

9. ábra Ceftriaxon nano-részecskék ciklikus voltammogramja aszkorbinsavval és anélkül vérsavó közegben; mérö elektróda: GCE, referencia elektróda: Ag/ $\mathrm{AgCl}$

\subsection{Effect of ascorbic acid on ceftriaxone nano-particles in blood serum}

One of the anti-oxidative reagents is ascorbic acid (AA) that can be used in electrochemical analysis, especially the voltammetric technique, to determine the oxidation-reduction current peaks of ceftriaxone nanoparticles in blood serum medium. Fig. 9 shows the influence of AA on the enhancement of the cathodic current peak of the nano-particles of the antibiotic in blood serum medium which is enhanced and another reduction peak appeared to increase the anti-oxidative effect gaining the free radicals from the blood medium through the process. So, it can be said that using AA solution with nano antibiotic drug of ceftriaxone provides more safety [15].

\section{Conclusions}

Ceftriaxone compound was converted into nano-particles and studied by cyclic voltammetric technique to find the electrochemical behavior in blood serum medium at different $\mathrm{pH}$ and with ascorbic acid solution. It was found that ceftriaxone micro- and nano-particles can be considered as antioxidative antibiotic reagent in alkaline blood serum medium which showed two cathodic current peaks to appear and the oxidation current peak to disappear in the cyclic voltammogram. The study was indicated that ceftriaxone compound in both microand nano-particles are good antioxidant antibiotic reagents in alkaline blood medium especially with ascorbic acid.

\section{References}

[1] Muhammed Mizher Radhi, - Zuhair Numan Hamed, - Selda Sabah Ezzaldeen, - Emad Abbas Jaffar Al-Mulla (2017): Effect of Microand Nanoparticles of Ampicillin Trihydrate on Blood Medium: A Voltammetric Study. Nano Biomedicine and Engineering, 2017, Vol. 9, No. 3, pp. 185-190. https://doi.org/10.5101/nbe.v9i3.p185-190.

[2] Radhi, M. M. - Khalaf, M. S. - Ali, Z. O. - Omran, R. I. (2016): Voltammetric analysis of $\mathrm{Zn}$ (II) in present of each ascorbic acid (AA) and folic acid (FA) in human blood samples. AASCIT Communications, Vol. 3 , No. 1, pp. 113-119.

[3] Yousif Kadhim Abdul-Amir, - Muhammed Mizher Radhi, - Emad Abbas Jaffar Al-Mulla (2017): Use of Nano-Sensors of the Interferences between $\mathrm{Pb}$ ((II) with Each of $\mathrm{Mg}(\mathrm{II}), \mathrm{Zn}(\mathrm{II}), \mathrm{Mn}(\mathrm{II}), \mathrm{Ca}(\mathrm{II}), \mathrm{Co}(\mathrm{II})$ and PO4-3 in Blood Medium: An Electrochemical Study, Nano Biomedicine and Engineering, 2017, Vol. 9, No. 3, pp. 199-207. https://doi.org/10.5101/nbe.v9i3.p199-207

[4] Radhi, M. M. - Abdul-Amir, Y. K. - Khalaf, M. S. (2016): Electrochemical Effect of Acetylsalicylic Acid (Aspirin) in Present of Each Ascorbic Acid (AA) and Folic Acid (FA) in Normal Saline and Human Blood Samples, American Association for Science and Technology, AASCIT Communications, Vol. 3, No. 3, pp. 152-159.

[5] Radhi, M. M. - Al-Dulimy, W. G. - Khalaf, M. S. (2016): Electrochemical study of selenium (IV) mediated by carbon nanotubes modified glassy carbon electrode in blood medium, Épitöanyag-Journal of Silicate Based and Composite Materials, Vol. 68, No. 3, pp. 90-93. https://doi.org/10.14382/epitoanyag-jsbcm.2016.16

[6] Radhi, M. M. - Abdullah, H. N. - Jabir, M. S. - Al-Mulla, E. A. J. (2017): Electrochemical effect of ascorbic acid on redox current peaks of $\mathrm{CoCl} 2$ in blood medium, Nano Biomedicine and Engineering, 2017, Vol. 9, No. 2, pp. 103-106. https://doi.org/10.5101/nbe.v9i2.p103-106

[7] Schichor, A. - Bernstein, B. - Weinerman, H. - Fitzgerald, J. - Yordan, E. Schechter, N. (1994): Lidocaine as a diluent for ceftriaxone in the treatment of gonorrhea, Archives of Pediatrics and Adolescent Medicine, Vol. 148, No. 1, pp. 72-75. https://doi.org/10.1001/archpedi.1994.02170010074017

[8] Majdi, S. - Jabbari, A. - Heli, H. - Yadegari, H. - Moosavi-Movahedi, A. A. - Haghgoo, S. (2009): Electrochemical oxidation and determination of ceftriaxone on a glassy carbon and carbon-nanotube-modified glassy carbon electrodes, 2009, Journal of Solid State Electrochemistry, Vol. 13, No. 3, pp. 407-416. https://doi.org/10.1007/s10008-008-0567-6

[9] Couto, R. A. S. - Quinaz, M. B. (2016): Development of a Nafion/ MWCNT-SPCE-Based Portable Sensor for the Voltammetric Analysis of 
the Anti-Tuberculosis Drug Ethambutol. Sensors, 2016, Vol. 16, No. 7, p. 1015. https://doi.org/10.3390/s16071015

[10] Shahrokhian, S. - Ranjbar, S. - Ghalkhani, M. (2016): Modification of the Electrode Surface by Ag Nanoparticles Decorated Nano Diamondgraphite for Voltammetric Determination of Ceftizoxime. Electroanalysis, Vol. 28, No. 3, 2016, pp. 469-476, https://doi.org/10.1002/elan.201500377

[11] Beytur, M. - Kardaş, F. - Akyıldırım, O. - Özkan, A. - Bankoğlu, B. Yüksek, H. - Yola, M. L. - Atar, N. (2018): A highly selective and sensitive voltammetric sensor with molecularly imprinted polymer based silver@ gold nanoparticles/ionic liquid modified glassy carbon electrode for determination of ceftizoxim, Journal of Molecular Liquids, Vol. 251, pp. 212-217. https://doi.org/10.1016/j.molliq.2017.12.060

[12] Sar, T. K. - Mandal, T. K. - Samanta, I. - Rahaman, A. - Chakraborty, A. K. (2010): Determination of ceftriaxone in plasma and ceftizoxime in milk of mastitic cows following single dose intravenous administration, Indian Journal of Animal Sciences, Vol. 80, No. 12, pp. 1182-1184, ref. 14.

[13] Abdelwahed, W. - Degobert, G. - Stainmesse, S. - Fessi, H. (2006): Freezedrying of nanoparticles: formulation, process and storage considerations. Advanced Drug Delivery Reviews, 2006, Vol. 58, No. 15, pp. 1688-1713. https://doi.org/10.1016/j.addr.2006.09.017
[14] Sochor, J. - Dobes, J. - Krystofova, O. - Ruttkay-Nedecky, B. - Babula, P. - Pohanka, M. - Jurikova, T. - Zitka, O. - Adam, V. - Klejdus, B. - Kizek, R. (2013): Electrochemistry as a Tool for Studying Antioxidant Properties. International Journal of Electrochemical Science, 2013, Vol. 8, pp. 8464$8489 \mathrm{http} / / /$ www.electrochemsci.org/papers/vol8/80608464.pdf

[15] Engin, C. - Yilmaz, S. - Saglikoglu, G. - Yagmur, S. - Sadikoglu, M. (2015): Electroanalytical Investigation of Paracetamol on Glassy Carbon Electrode by Voltammetry, International Journal of Electrochemical Science, 2015, Vol. 10, pp. 1916-1925.

http://www.electrochemsci.org/papers/vol10/100201916.pdf

Ref.:

Radhi, Muhammed Mizher - Khelkal, Intesar Nadhum - Naji, Eman Natiq - Abdullah, Alaa Laebi: Electrochemical characterization of micro- and nano-particles of ceftriaxone in human blood serum samples using cyclic voltammetry

Építöanyag - Journal of Silicate Based and Composite Materials, Vol. 71, No. 2 (2019), 52-56. p.

https://doi.org/10.14382/epitoanyag-jsbcm.2019.10

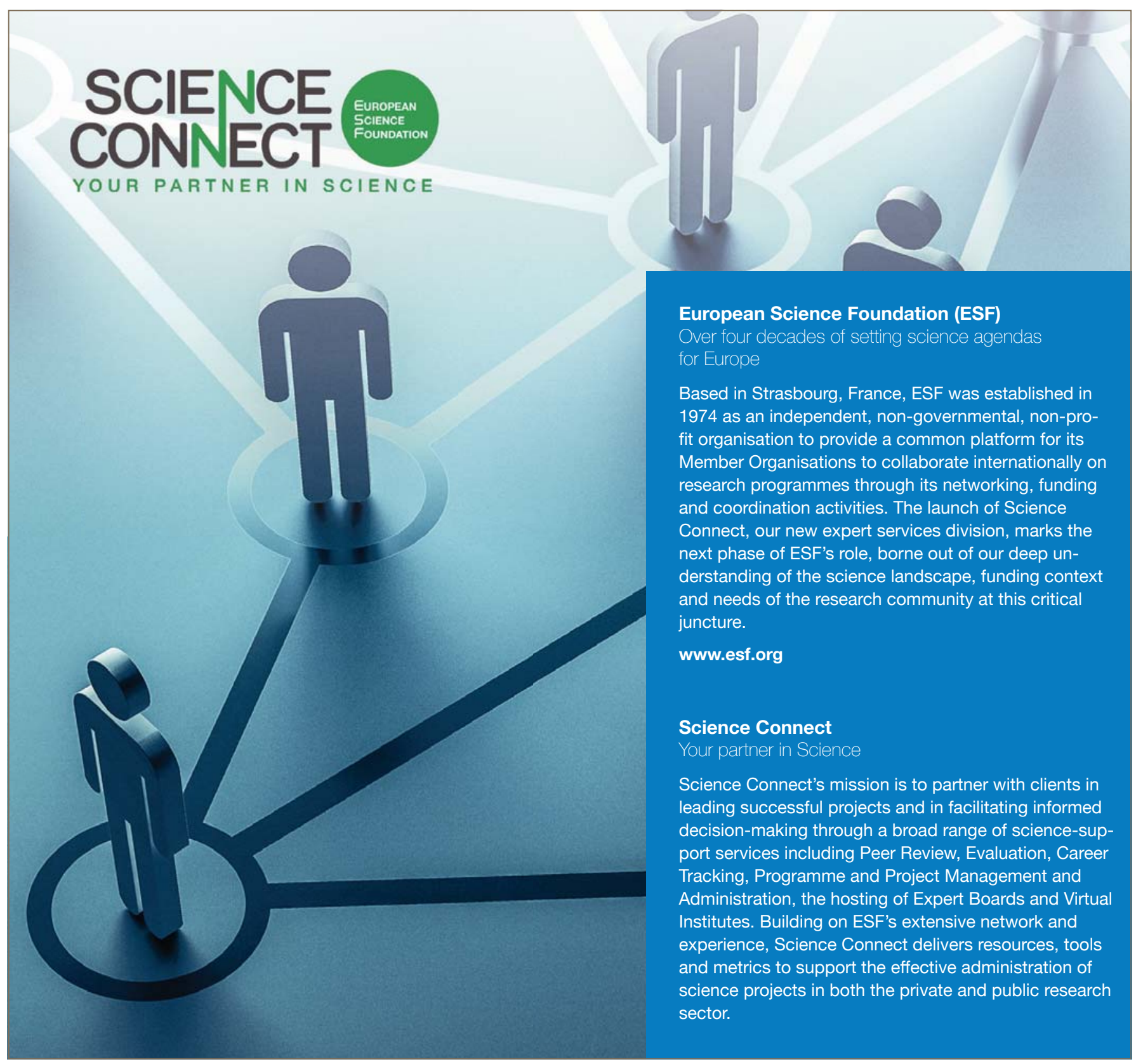

